\title{
STEREOTIP GENDER DALAM PROFESI GURU PENDIDIKAN ANAK USIA DINI
}

\author{
Evi Resti Dianita \\ Institut Agama Islam Negeri Jember \\ evirestidianita@gmail.com
}

\begin{abstract}
The phenomenon of the scarcity of men to work as early childhood education teachers makes people assume that the profession is more suitable for women, so that there is an imbalance in gender roles in early childhood education institutions. But the discussion of gender issues surrounding the profession of early childhood education teachers still seems to often escape from our attention. This is the background for choosing this issue. The purpose of this study is to describe gender stereotypes in the early childhood education teacher profession and provide an alternative view of the importance of men's roles in this field. The approach used is a qualitative approach and the type is library research. Based on the discussion and analysis, it was concluded that gender stereotypes in the early childhood education teacher profession are at least tangible in three ways: a) existence of feminine identity attached to this profession and it is far from masculinity, so men are less interested in teaching young children; b) early childhood education teachers are considered as a profession with a minimum risk so that it is less challenging and considered more appropriate for women; c) early childhood education teachers are low-paid jobs and are considered more appropriate for women.
\end{abstract}

Keywords : gender stereotipe, early childhood education teacher

\begin{abstract}
Abstrak
Fenomena langkanya laki-laki yang berprofesi sebagai guru pendidikan anak usia dini menjadikan masyarakat beranggapan bahwa profesi guru PAUD lebih sesuai untuk perempuan, sehingga terjadi ketidak-seimbangan peran gender di lembaga PAUD. Namun pembahasan tentang isu gender yang mengitari profesi guru pendidikan anak usia dini tampaknya masih seringkali luput dari perhatian kita. Hal inilah yang melatarbelakangi dipilihnya isu ini. Tujuan dari penelitian ini adalah untuk mendeskripsikan tentang stereotip gender dalam profesi guru PAUD serta memberikan pandangan alternatif tentang pentingnya peran laki-laki sebagai guru PAUD. Pendekatan yang digunakan dalam penelitian ini adalah pendekatan kualitatif dengan jenis riset kepustakaan. Berdasarkan diskusi dan analisis disimpulkan bahwa stereotip gender dalam profesi guru pendidikan anak usia dini setidaknya berwujud dalam tiga hal : a) pemberian identitas feminim dan jauh dari kesan maskulin, sehingga laki-laki kurang tertarik mengajar anak usia dini; b) guru PAUD dianggap sebagai profesi dengan minim risiko (low-risk) sehingga kurang menantang dan yang dipandang lebih sesuai untuk sektor ini adalah perempuan; c) guru PAUD adalah pekerjaan bergaji rendah dan dianggap lebih sesuai dilakukan oleh perempuan.
\end{abstract}

Kata Kunci: stereotip gender, guru pendidikan anak usia dini 


\section{Pendahuluan}

Manusia adalah makhluk Allah yang diciptakan dengan jenis laki-laki dan perempuan sebagai kodratnya. Meskipun secara fisik banyak perbedaan, namun Al-Qur'an mengajarkan keduanya mempunyai kedudukan yang sama di hadapan Tuhannya, setara, tidak ada diskriminasi dan saling melengkapi. ${ }^{1}$ Namun demikian, fungsi, peran dan kedudukannya secara sosial dan politik masih sangat erat dengan pengaruh kultur yang berlaku di masyarakat. Terlebih di Indonesia kebudayaan patriarkhi masih sangat kental dan dipegang teguh oleh sebagian besar masyarakatnya. Adanya pengaruh kultur yang cukup kuat menyebabkan peran dan kedudukan laki-laki dan perempuan cenderung dibedakan berdasarkan perbedaan fisik. Inilah yang seringkali menimbulkan kesenjangan, tak terkecuali di dunia kerja. Partisipasi laki-laki dan perempuan di dunia kerja turut menjadi sektor yang rentan dikaitkan dengan gender dan stereotip masyarakat.

Fenomena guru Pendidikan Anak Usia Dini (PAUD) yang cenderung didominasi oleh perempuan sudah menjadi hal yang dianggap lumrah dan dianggap wajar di masyarakat. ${ }^{2}$ Sampai kini peran profesi guru Pendidikan Anak Usia Dini dan Taman Kanak-Kanak (TK) masih terkesan lebih lekat pada kaum perempuan dan justru dianggap kurang sesuai bila dilakukan oleh laki-laki. Memang pada umumnya guru yang mengajar di PAUD ataupun TK didominasi oleh jenis kelamin perempuan, baik yang sudah menikah maupun yang belum menikah. Bila diamati di lapangan, sulit bagi kita menemukan guru PAUD ataupun TK dari jenis kelamin laki-laki. Dari sekian banyak guru PAUD dalam suatu kecamatan barangkali laki-laki dapat dihitung dengan jari jumlahnya atau hampir tidak ada sama sekali. Di sebuah lembaga PAUD di Kabupaten Jember, seluruh tenaga pendidiknya adalah perempuan. Tak ada satupun tenaga pendidik laki-laki. Ini berbanding lurus dengan laporan data statistik PAUD yang dirilis oleh Pusat Data dan Statistik Pendidikan dan Kebudayaan Kemendikbud RI, jumlah guru dan kepala sekolah TK laki-laki di Indonesia 10.330 orang, sedangkan jumlah guru dan kepala sekolah TK perempuan di Indonesia mencapai 303.317 orang. Artinya, perbandingan jumlah laki-laki dan perempuan adalah $1: 30$ orang.

Fenomena langkanya laki-laki yang menjadi guru PAUD atau TK menjadikan masyarakat beranggapan bahwa biasanya yang menjadi guru PAUD atau guru TK adalah perempuan. Artinya, terdapat anggapan baku di masyarakat kita terhadap kepantasan perempuan dalam mengajar anak-anak usia dini karena dianggap lebih mampu daripada laki-laki, sehingga menjadikan guru PAUD laki-laki menjadi langka.

Sebagai contoh, penelitian yang dilakukan oleh Sum dan Talu menemukan bahwa sebagian masyarakat mempunyai persepsi bahwa tugas untuk mengasuh dan mendidik anak usia dini adalah tugas seorang perempuan. ${ }^{3}$ Menurut mereka hal ini disebabkan oleh beberapa alasan, yaitu : (1) perempuan lebih tabah dalam

\footnotetext{
${ }^{1}$ QS. Al-Baqarah (2) : 187; QS. An-Nisa (4) : 1; QS. Ar-Rum (30) : 21; QS. Al-Hujurat (49) : 13; QS. An-Nahl (16) : 97; QS. At-Taubah (9) : 71.

${ }^{2}$ Kementerian Pendidikan et al., 2017 2018, ed. Pusat Data Statistik Pendidikan dan Kebudayaan (Jakarta: Kemendikbud RI, 2018).

3 Theresia Alviani Sum, Adriani Tamo, and Ina Talu, "Faktor Penyebab Kurangnya Minat Laki-Laki Untuk Menjadi Guru Paud Di Kabupaten Manggarai,” Missio, no. 10 (2003): 192203, http://jurnal.unikastpaulus.ac.id/index.php/jpkm/article/view/170/139.
} 
menghadapi anak-anak, (2) sudah menjadi tugas perempuan sejak zaman dahulu kala, dari segi budaya Manggarai yang berpegangan pada hukum patriarkat, menganggap bahwa perempuan memiliki tugas melahirkan, mendidik dan mengasuh anak sedangkan laki- laki hanya bertugas untuk mencari nafkah. Dari penelitian tersebut dapat diketahui bahwa sebagian masyarakat di Indonesia sangat dipengaruhi oleh nilai-nilai budaya yang berlaku, termasuk juga dalam menyikapi peran perempuan dalam mendidik anak. Nilai budaya patriarki menjadi salah satu alasan bahwa perempuan harus menjadi pihak yang paling pantas berperan mendidik.

PAUD masih menghadapi pekerjaan rumah yang serius dan tak kunjung usai terkait ketidakseimbangan peran laki-laki dan perempuan dalam praktik pendidikan di lembaganya. Di antara berbagai jenis pekerjaan dan profesi, guru PAUD merupakan salah satu yang mencolok karakternya karena cenderung diciterakan sebagai profesi yang selalu dijalankan oleh perempuan sejak dahulu hingga saat ini.

Fenomena langkanya laki-laki yang mengajar anak-anak usia dini rupanya tidak hanya terjadi di Indonesia saja. Di beberapa negara lain, di Hong Kong misalnya, pun terjadi hal yang hampir sama. Ho \& Lam melaporkan bahwa jumlah guru PAUD yang berjenis kelamin laki-laki hanya sebanyak $1.2 \%$ dari jumlah keseluruhan guru. Sedangkan di Taiwan, persentase jumlah guru laki-laki hanya mencapai 1.6\%.4 Keadaan yang hampir sama juga berlaku di bebagai belahan dunia lain, seperti di Kanada (3.4\%), Amerika Serikat (2\%), Selandia Baru (2\%), bahkan Australia dengan angka 2.6\%.5 Bahkan di Uni Emirat Arab, sebagaimana yang dikemukakan oleh Irianto dkk, seratus persen guru taman kanak-kanaknya adalah perempuan. 6

Di Irlandia, sebuah hasil survei yang dilakukan oleh Komite Pendidikan Anak Usia Dini pada tahun 2012 dan 2013 menunjukkan bahwa dari sekitar 328 lembaga pendidikan anak usia dini di 13 negara bagian, 77\% lembaga pendidikan anak usia dini tidak memiliki tenaga pendidik laki-laki. ${ }^{7} \mathrm{Hal}$ ini berdasarkan sebuah survei yang telah dilakukan oleh Walshe (2012) yang bertujuan untuk mencari penyebab kelangkaan guru laki-laki di Irlandia. Hasil survei tersebut juga menunjukkan bahwa masyarakat masih memberikan stereotip negatif terhadap guru laki-laki yang menjadi pengajar pada jenjang pendidikan anak usia dini. Sebuah media independent.ie pada tahun 2016, seorang presiden organisasi persatuan guru di Irlandia (INTO), Rosena Jordan, mengungkapkan bahwa pria

\footnotetext{
4 Dora Ho and Haze Lam, "A Study of Male Participation in Early Childhood Education: Perspectives of School Stakeholders," International Journal of Educational Management 28, no. 5 (2014): 498-509, https://doi.org/10.1108/IJEM-02-2013-0024.

5 Akhmad Mukhlis, "Dominasi Guru Perempuan Dalam Pendidikan Anak Usia Dini: Persepsi Stakeholder," Al-Athfal Jurnal Pendidikan Anak 5, no. 2 (2019): 117-34, http://ejournal.uin-suka.ac.id/tarbiyah/index.php/alathfal/article/view/2619/1753.

${ }^{6}$ Sulistyowati Irianto et al., Akses Keadilan Dan Migrasi Global: Kisah Perempuan Indonesia Pekerja ... (Jakarta: Yayasan Pustaka Obor Indonesia, 2011).

7 Theresia Alviani Sum, "Opini: PAUD Dan Peran Guru Laki-Laki | Florespost.Co," Florespost.Co, June 4, 2018, https://www.florespost.co/2018/06/04/opini-paud-danperan-guru-laki-laki/.
} 
telah menghilang dari ruang kelas Irlandia sejak tahun 1970-an. Kini hanya di bawah 15 persen. 8

Berbagai gambaran tersebut menujukkan bahwa rendahnya partisipasi kaum laki-laki dalam penyelenggaraan pendidikan anak usia dini tidak hanya menjadi problem nasional, tapi juga problem global. Di tengah gencarnya usaha dunia mewujudkan keadilan sosial bagi masyarakat terutama di negara-negara yang mempraktikkan sistem demokrasi, problem ketimpangan antara laki-laki dan perempuan masih saja terjadi dan tidak mudah dihilangkan. Meskipun gender mempunyai pengaruh dalam mengukur indeks demokrasi suatu negara, namun indeks penerapan demokrasi itu sendiri tidak selalu berbanding lurus dengan kesetaraan gender yang baik.

Di Indonesia sendiri seringkali problem ketimpangan gender seperti ini masih terjadi, termasuk dalam konteks pendidikan anak usia dini. Namun pembahasan tentang isu gender yang mengitari profesi guru pendidikan anak usia dini seringkali luput dari perhatian kita. Justru di jenjang pendidikan anak usia dini lah fase awal tersemainya bibit-bibit keadilan gender sejak dini. Di sisi lain aspek keseimbangan peran antara laki-laki dan perempuan lebih diperhatikan untuk mempermudah mengevaluasi sejauh mana efektivitas dan optimalitas pendidikan anak usia dini perihal dominasi perempuan sebagai tenaga pendidiknya. Dalam hal inilah penulis menganggap topik ini menarik untuk dikaji sehingga disusunlah artikel ini. Adapun masalah-masalah yang menjadi fokus utama dalam penelitian ini meliputi hal-hal berikut : (1) Konsep gender dan seks; (2) stereotip gender dalam profesi guru pendidikan anak usia dini; (3) laki-laki dalam pendidikan anak usia dini.

\section{Tinjauan Literatur}

Sebuah penelitian yang dilakukan oleh Akhmad Mukhlis pada tahun 2019, bertujuan untuk melihat persepsi stakeholder terkait dominasi perempuan dan minimnya partisipasi laki-laki sebagai guru pendidikan anak usia dini (PAUD). Hasil penelitian menunjukkan bahwa stakeholder menganggap perempuan memiliki kompetensi lebih baik dibanding laki-laki dalam PAUD. Stakeholder juga berpandangan bahwa laki-laki dapat berpartisipasi dan berkontribusi terutama dalam pengembangan kegiatan fisik-motorik, seni, contoh peran gender bagi peserta didik laki-laki dan juga mengisi peran kepemimpinan dalam lembaga PAUD. Untuk mengatasi rendahnya partisipasi laki-laki dalam PAUD, diharapkan dukungan kebijakan pemerintah dan juga universitas dalam mengembangkan calon guru PAUD laki-laki. ${ }^{9}$ Fakta tersebut menunjukkan bahwa persepsi stakeholder terhadap kualitas pendidikan anak usia dini sebetulnya masih tidak dapat dilepaskan dari stereotip gender. Dengan menganggap kaum ibu lebih ideal dibandingkan kaum bapak, maka dapat mendorong dominasi guru perempuan dalam sebuah lembaga PAUD dan taman kanak-kanak.

8 Rosena Jordan, "Why We Need More Male Teachers and More Female Principals Independent.Ie," Independent.ie, 2016, https://www.independent.ie/irishnews/education/going-to-college/why-we-need-more-male-teachers-and-more-femaleprincipals-35083784.html.

9 Mukhlis, 'Dominasi Guru Perempuan Dalam Pendidikan Anak Usia Dini'. 
Sebelumnya Gomes dalam hasil penelitiannya pada tahun 2008 mengemukakan bahwa dominasi perempuan dalam profesi guru PAUD merupakan bentuk subordinasi perempuan oleh laki-laki. Dominasi perempuan dalam profesi guru PAUD berdampak pada konsep peran gender anak usia dini. Kondisi di mana semua gurunya adalah ibu dapat membentuk persepsi anak usia dini, yakni 'guru adalah ibu dan bukan bapak'. Selanjutnya, konsep peran gender seperti ini dapat melahirkan stereotip gender terhadap profesi guru PAUD dalam diri seorang anak. Dampak lainnya adalah penyelenggaraan kegiatan PAUD yang responsif gender menjadi lebih sulit sebab sejak dini anak usia dini sudah memiliki persepsi yang bias gender terhadap profesi guru PAUD yang selanjutnya diperkuat oleh stereotip peran gender dalam masyarakat akan profesi ini. Pada akhirnya efek tersebut dapat menyebabkan penyelenggaraan Program Studi Pendidikan Guru PAUD di perguruan tinggi yang juga bias gender. ${ }^{10}$

Kedua penelitian tersebut turut menjadi dasar dari sebuah argumentasi bahwa persepsi para pihak di luar maupun di dalam lembaga PAUD menjadi faktor krusial dalam membangun stereotip. Mengubah persepsi memang merupakan sasaran yang strategis bagi banyaknya kajian seputar gender. Namun meskipun sudah dikaji sejak waktu yang lama, nampaknya pemahaman yang benar tentang gender belum secara menyeluruh sampai di masyarakat sehingga permasalahan gender masih menjadi salah satu isu prioritas untuk dibahas.

\section{Metode}

Penelitian ini menggunakan pendekatan deskriptif kualitatif. Adapun jenis penelitian ini adalah penelitian kepustakaan (library research) yaitu mengumpulkan data atau karya tulis ilmiah yang bertujuan dengan objek penelitian atau pengumpulan data yang bersifat kepustakaan. Sebagaimana yang dikemukakan oleh Zed bahwa riset kepustakaan merupakan serangkaian kegiatan yang berkenaan dengan metode pengumpulan data pustaka, membaca dan mencatat serta mengolah bahan penelitian. ${ }^{11}$ Sumber data dalam penelitian ini menggunakan personal document sebagai sumber data-data penelitian, seperti buku dan penelitian-penelitan terdahulu. Teknik pengumpulan data yaitu dilakukan dengan mengidentifikasi berbagai bahan pustaka mulai dari buku, artikel ataupun jurnal dan informasi lainnya yang berhubungan dengan judul penelitian serta mengumpulkan bahan, mencatat dan menganalisis data-data pustaka yang diperoleh. Adapun tahap-tahap dalam penelitian ini ialah sebagaimana yang dikemukakan oleh Zed (2004) yaitu : (1) menyiapkan alat perlengkapan yang diperlukan; (2) menyiapkan bibliografi kerja; (3) mengorganisasikan waktu; dan (4) kegiatan membaca dan mencatat bahan penelitian. ${ }^{12}$

10 Fransiskus de Gomes, "DAMPAK DOMINASI PEREMPUAN DALAM PROFESI GURU PAUD," Jurnal Inovasi Pendidikan Dasar 2, no. 1 (2008): 86-97.

${ }_{11}$ Mestika Zed, Metode Penelitian Kepustakaan, 2nd ed. (Jakarta: Yayasan Pustaka Obor Indonesia, 2008).

12 Zed. 


\section{Hasil dan Diskusi}

\section{Konsep Gender dan Seks}

Sebetulnya isilah gender bukanlah sesuatu yang baru bagi sebagian orang, termasuk bagi kalangan feminis. Namun sementara ini masih ada juga sebagian orang keliru dalam memahami istilah gender, sehingga konsep kesetaraan gender seringkali dipandang sinis dan sulit diterima, terutama bagi kalangan masyarakat awam. Hal ini menjadi sangat masuk akal bila dikaitkan dengan kekeliruan pandangan masyarakat dalam mendefinisikan kata gender dan kegagalan dalam mengkontekstualisasikan istilah tersebut dalam kehidupan sehari-hari. Minimnya akses masyarakat terhadap literasi gender masih menjadi salah satu penyebab utamanya. Hal ini pun membuat pengetahuan masyarakat tidak utuh dan setengah-setengah sehingga cenderung mengundang reaksi penolakan. Padahal pengetahuan yang benar terhadap gender sangat penting agar kita tidak salah paham dalam menerima konsep yang bagi sebagian orang masih dianggap hal baru dan tabu tersebut.

Istilah gender secara bahasa berasal dari bahasa Inggris, "gender", yang maknanya adalah jenis kelamin. Berkaca pada definisi ini, mulanya kata gender memang secara bahasa dipergunakan untuk menegaskan perbedaan jenis laki-laki dan perempuan secara biologis. Kita tahu bahwa jenis kelamin laki-laki dan perempuan memiliki banyak sekali hal pembeda yang bisa tampak dari luar. Hal inilah yang ditujukan oleh pemaknaan gender secara etimologis. Ini mempunyai kesamaan dengan definisi dari kata "sex" yang dalam bahasa Inggris juga mempunyai arti jenis kelamin. Namun belakangan kata gender mempunyai makna yang lebih spesifik secara terminologis dan tidak serta-merta dianggap sebagai jenis kelamin saja.

Gender ialah suatu konsep yang digunakan untuk membedakan antara lakilaki dan perempuan dari sudut non-biologis. ${ }^{13}$ Istilah gender kemudian dibedakan dari istilah 'seks'. Oakley (1997), seorang ahli Sosiologi Inggris, merupakan tokoh yang mula-mula memberikan pembedaan terhadap kedua istilah tersebut. Istilah gender merujuk kepada perbedaan karakter laki-laki dan perempuan berdasarkan kontruksi sosial budaya, yang berkaitan dengan sifat, status, posisi dan perannya dalam masyarakat. ${ }^{14}$

Menurut WHO, yang dikutip dari laman resminya www.who.int, gender mengacu pada peran (roles), perilaku (behaviors), kegiatan (activities), atribut (attributes), dan peluang (opportunities) yang dianggap cocok oleh masyarakat mana pun untuk anak perempuan dan laki-laki, serta perempuan dan laki-laki. Gender berkaitan erat dengan seks-jenis kelamin, tetapi berbeda dengan istilah tersebut. ${ }^{15}$ Selanjutnya, melalui http://www.euro.who.int ditegaskan pula mengenai definisi gender sebagaimana berikut : Gender is used to describe the

13 Janu Arbain, Nur Azizah, and Ika Novita Sari, "PEMIKIRAN GENDER MENURUT PARA AHLI: Telaah Atas Pemikiran Amina Wadud Muhsin, Asghar Ali Engineer, Dan Mansour Fakih," Sawwa: Jurnal Studi Gender 11, no. 1 (June 7, 2017): 75, https://doi.org/10.21580/sa.v11i1.1447.

14 Ratna Saptari, Brigitte M. Holzner, and Kalyanamitra, Perempuan, Kerja, Dan Perubahan Sosial: Sebuah Pengantar Studi Perempuan (Pustaka Utama Grafiti, 1997), https:/ / books.google.co.id/books/about/Perempuan_kerja_dan_perubahan_sosial.html?hl $=\mathrm{id} \& \mathrm{id}=\mathrm{jHDaAAAAMAAJ} \&$ redir_esc $=\mathrm{y}$.

15 “Gender," accessed June 9, 2020, https://www.who.int/health-topics/gender\#tab=tab_1. 
characteristics of women and men that are socially constructed, while sex refers to those that are biologically determined. People are born female or male, but learn to be girls and boys who grow into women and men. This learned behaviour makes up gender identity and determines gender roles. ${ }^{16}$ Berdasarkan definisi yang dikemukakan oleh WHO tersebut gender digunakan untuk menggambarkan karakteristik perempuan dan laki-laki yang dikonstruksi secara sosial, sedangkan seks mengacu pada karakteristik yang ditentukan secara biologis. Orang yang dilahirkan perempuan atau laki-laki, tetapi belajar menjadi perempuan dan lakilaki-lah yang tumbuh menjadi pribadi perempuan atau laki-laki. Perilaku yang dipelajari ini membentuk identitas gender dan menentukan peran gendernya kemudian.

Berbeda halnya dengan definisi istilah seks, makna seks lebih dekat dengan ciri fisik-biologis dari manusia. Menurut Lind dan Brzuzy (2008), sex refers to biological differences between males and females in any given species. ${ }^{17}$ Seks mengacu pada perbedaan biologis antara jenis jantan dan betina pada spesies apa pun, termasuk pada manusia di mana ada jenis kelamin laki-laki dan perempuan. Perbedaan biologis tersebut kemudian memiliki banyak sekali spesifikasi dan karakteristik yang menjadikan keduanya mempunyai ciri khas pembeda satu sama lain.

Karakteristik seksual seringkali dibedakan menjadi karakteristik primer dan sekunder. Karakteristik seksual primer pada wanita secara biologis terdiri dari ovarium, uterus dan vagina, dengan karakteristik seksual sekunder meliputi perkembangan payudara dan pinggul dan kontur wajah. Sedangkan karakteristik seksual utama pada pria meliputi penis dan testis sementara karakteristik seksual sekundernya seperti timbulnya jakun dan pertumbuhan rambut di permukaan kulit yang lebih cepat, meskipun sebenarnya tumbuhnya rambut sangat dipengaruhi oleh faktor genetik. ${ }^{18}$

Secara alamiah, perbedaan-perbedaan tersebut sifatnya adalah tetap dan tidak dapat berubah seiring berjalannya waktu. Sampai kapanpun potensi yang dibawa sebagai konsekuensi karakteristik seksual tersebut pun tetap dan tidak bisa ditukar satu sama lain. Inilah mengapa seks itu merupakan kodrat alamiah yang dianugerahkan oleh Tuhan dan telah ada sejak kita dilahirkan.

Ini sangat berbeda dengan konsep gender yang bersifat dinamis dan dapat diubah. Yang dimaksud dengan gender adalah cara pandang atau persepsi manusia terhadap perempuan atau laki-laki yang bukan didasarkan pada perbedaan jenis kelamin secara kodrati atau secara biologis. ${ }^{19}$ Gender dalam segala aspek kehidupan manusia mengkreasikan perbedaan antara perempuan dan laki-laki termasuk kreasi sosial kedudukan perempuan yang lebih rendah dari pada laki-laki. Misalnya, bahwa perempuan itu dikenal lemah lembut, cantik, emosional atau keibuan. Sementara laki-laki dianggap kuat, rasional, jantan,

16 "Gender: Definitions," WHO Europe, 2002, https://www.euro.who.int/en/healthtopics/health-determinants/gender/gender-definitions.

17 Stephanie Brzuzy and Amy Lind, Battleground: Women, Gender, and Sexuality [2 Volumes], Greenwood Press (Westport, Connecticut, 2008).

${ }^{18}$ Brzuzy and Lind.

19 Evy Clara and Ajeng Agrita Dwikasih Wardani, Sosiologi Keluarga (Jakarta: UNJ Press, 2020). 
perkasa. Ciri dari sifat itu sendiri merupakan sifat-sifat yang dapat dipertukarkan. Artinya ada pula laki-laki yang emosional, lemah lembut, keibuan, sementara juga ada perempuan yang kuat, rasional dan perkasa. ${ }^{20}$

Gender hanya memuat peran dan fungsi sosial laki-laki dan perempuan yang terbentuk oleh lingkungan tempat kita berada. Gender tercipta melalui proses sosial budaya yang panjang dalam suatu lingkup masyarakat tertentu, sehingga dapat berbeda dari satu tempat ke tempat lainnya. ${ }^{21}$ Oleh karena itu, gender dan seks merupakan dua hal yang berbeda, namun keduanya mempunyai keterkaitan erat. Konsep gender yang sedang dibicarakan bukanlah jenis kelamin perempuan ataupun laki-laki. Akan tetapi konsep mengenai peran dan fungsi yang dijalankan oleh perempuan dan laki-laki yang dipengaruhi oleh perbedaan seks/jenis kelamin berdasarkan konstruk berpikir masyarakat. Konstruksi berpikir ini boleh jadi diwarnai oleh faktor-faktor sosial maupun budaya yang dimiliki oleh setiap komunitas masyarakat seperti sistem nilai, keyakinan, adat-istiadat, kebiasaan dan sebagainya, serta ditentukan pula oleh faktor waktu maupun tempat di mana komunitas masyarakat tersebut berada. Sehingga boleh jadi konsep gender antar masyarakat di suatu tempat dengan tempat yang lainnya berbeda.

\section{Stereotip Gender Dalam Profesi Guru PAUD}

Salah satu permasalahan besar yang dihadapi oleh Indonesia saat ini ialah ketimpangan gender. Sebuah hasil riset yang dilaporkan oleh The Global Gender Gap Index $2020^{22}$ menunjukkan bahwa Indonesia berada pada peringkat 85 dari 153 negara dengan skor 0.70 dan tidak berubah dari tahun 2018. Peringkat tersebut masih tertinggal jauh dari negara-negara tetangga, seperti Filipina pada urutan 16, Laos pada urutan 43, Singapura pada urutan 54 dan Thailand pada urutan 75.23 Ini menunjukkan bahwa Indonesia belum banyak mengalami perubahan yang signifikan setidaknya dalam dua tahun terakhir dilihat dari segi ketimpangan gender.

Di antara contoh nyata dari penyebab fenomena ketimpangan gender tersebut adalah adanya stereotip. Definisi stereotip dalam bahasa Indonesia adalah konsepsi mengenai sifat suatu golongan berdasarkan prasangka yang subjektif dan tidak tepat. ${ }^{24}$ Menurut Merwe, istilah stereotip dalam ilmu sosial muncul pertama kali dalam karya Lippmann yang berjudul Public Opinion (1922). ${ }^{25}$ Lippmann dalam bukunya tersebut menunjukkan bagaimana pandangan orang-orang tentang dunia diwarnai oleh serangkaian prasangka dan prasyarat, yang ditransmisikan dari

20 Moerti Hadiati Soeroso, Kekerasan Dalam Rumah Tangga Dalam Perspektif YuridisViktimologis (Sinar Grafika, 2010).

21 Wiliam-de Vries D., Gender Bukan Tabu: Catatan Perjalanan Fasilitasi Kelompok Perempuan Di Jambi, Gender Bukan Tabu: Catatan Perjalanan Fasilitasi Kelompok Perempuan Di Jambi (Bogor: Center for International Forestry Research (CIFOR), 2006), https://doi.org/10.17528/cifor/002133.

${ }^{22}$ World Economic Forum, "Insight Report Global Gender Gap Report 2020 Terms of Use and Disclaimer" (Switzerland, 2019), www.weforum.org.

${ }_{23}$ Nopitri Wahyuni, "Indonesia Dalam Gender Gap Index 2020 Report: Beberapa Catatan," The Indonesian Institute, 2019, https://www.theindonesianinstitute.com/indonesia-dalamgender-gap-index-2020-report-beberapa-catatan/.

24 "Arti Kata Stereotip - Kamus Besar Bahasa Indonesia (KBBI) Online," accessed May 9, 2020, https://kbbi.web.id/stereotip.

${ }^{25}$ Chris N. van der Merwe, Breaking Barriers. Stereotypes and the Changing of Values in Afrikaans Writing 1875-1990 (Amsterdam: Rodopi, 1994). 
generasi ke generasi. Pandangan inilah yang dibagikan oleh sekelompok orang atau komunitas dan seringkali dilakukan tanpa disadari. Lippmann menyebutnya sebagai "stereotip". ${ }^{26}$ Dalam Public Opinion, Lippmann juga menyebutkan sifat-sifat berikut sebagai ciri dari stereotip:

a) It is characterised by simplification, atau ditandai dengan penyederhanaan

b) It is shared by many; spread by the mass media and transmitted from one generation to the next. Artinya, pandangan stereotip dibagikan oleh banyak orang; disebarkan oleh media massa dan ditransmisikan dari satu generasi ke generasi berikutnya.

c) It is resistant to change, atau tahan terhadap perubahan. ${ }^{27}$

Selain ciri-ciri di atas, Lakoff (1987) sebagaimana yang dikutip dalam Merwe (1994) juga menambahkan ciri lainnya dari stereotip, yaitu bertujuan membuat penilaian yang cepat terhadap orang lain. ${ }^{28}$ Sedangkan Secord dan Backman (1964) mengemukakan karakteristik stereotip sebagaimana berikut : Stereotyping has three characteristics : the categorization of persons, a consensus on attributed traits and a discrepancy between attributed traits and actual traits. ${ }^{29}$

Menurut Merwe, yang melekat dalam stereotip adalah perbedaan yang nampak jelas antara kategori 'baik' dan 'buruk', ada klasifikasi yang dapat diterima' versus 'yang tidak dapat diterima', dan penyederhanaan atau simplifikasi seseorang ke dalam salah satu dari dua kategori tersebut. Stereotip menentukan harapan budaya dan moral suatu kelompok sosial. Mereka mencerminkan dan mengkonfirmasi pandangan ideologis yang dipegang oleh anggota masyarakat. ${ }^{30}$

Stereotip dalam kalimat lain merupakan pemberian citra baku atau label atau cap kepada seseorang atau kelompok yang didasarkan pada suatu anggapan yang salah atau sesat. ${ }^{31}$ Pelabelan negatif seringkali dilakukan oleh seseorang berdasarkan anggapan gender. Pelabelan negatif kemudian menimbulkan citra negatif pada seseorang atau salah satu kelompok yang diikuti oleh perbedaan sikap dan perlakuan kepada seseorang atau kelompok tersebut. Perbedaan sikap dan perlakuan yang didasarkan atas gender merupakan salah satu bentuk dari ketidakadilan gender. Pola-pola seperti ini tidak baik apabila terus-menerus dilakukan secara berulang-ulang karena dapat memicu konflik dan ketimpangan sosial.

Profesi guru pendidikan anak usia dini merupakan salah satu yang tak luput dari pola stereotip. Guru pada lembaga PAUD dan taman kanak-kanak kerap diciterakan sebagai sosok perempuan. Hal ini dikarenakan memang jarang sekali guru PAUD ataupun TK yang berasal dari jenis laki-laki. Penulis sendiri di masa kecil (1993-1995) diajar dan dibimbing oleh guru-guru taman kanak-kanak yang semuanya adalah perempuan. Bahkan sempat tertanam di benak penulis bahwa di taman kanak-kanak itu hanya ada ibu guru, tidak ada bapak guru. Hanya saja

\footnotetext{
26 van der Merwe.

27 Walter Lippmann, "Stereotypes.," in Public Opinion. (MacMillan Co, 2015), 79-94, https://doi.org/10.1037/14847-006.

28 Merwe.

${ }^{29}$ Paul F. Secord and Carl W. Backman, Social Psychology - Paul F. Secord, Carl W. Backman (New York: McGraw Hill Book Company, 1964).

30 Merwe, Breaking Barriers.

31 "Glosary Ketidakadilan Gender," Kementerian Pemberdayaan Perempuan dan Anak Republik Indonesia, n.d.
} 
bedanya kalau di era 90-an ibu guru biasanya adalah perempuan yang sudah menikah atau memiliki anak dan berusia paruh baya. Berbeda dengan ibu guru di zaman kini yang banyak juga diperankan oleh gadis-gadis muda yang belum menikah.

Sebuah penelitian yang dilakukan oleh Ahmad Mukhlis (2019) menggambarkan kondisi pada Jurusan PGRA UIN Maulana Malik Ibrahim Malang yang dalam tiga angkatan terakhir di antara keseluruhan peserta didik yang memprogram hanya terdapat 2 orang mahasiswa dan lainnya adalah mahasiswi. ${ }^{32}$ Hal yang sama juga terjadi pada Prodi PIAUD IAIN Jember yang sejak pertama kali dibuka pada tahun 2015 hingga kini pun hanya terdapat 2 orang mahasiswa sedangkan yang lainnya adalah mahasiswi. ${ }^{33}$ Data sementara ini menunjukkan bahwa program studi pendidikan anak usia dini memang sejak awal tidak begitu diminati oleh calon peserta didik laki-laki. Jika calon guru PAUD laki-laki saja memang jarang, apalagi dengan guru PAUD laki-laki, tentu bisa dengan mudah kita prediksi. Jumlahnya pasti sangat sedikit. Berdasarkan data yang dirilis oleh Pusat Data dan Statistik Pendidikan dan Kebudayaan Tahun 2017, bahwa bila dipersentase jumlah guru perempuan di jenjang Taman Kanak-Kanak adalah 97,96\%, sedangkan guru laki-laki di TK hanya 2,04\%. ${ }^{34}$ Ini menjadi masuk akal karena biasanya di PAUD dan TK tidak ada guru laki-laki, kalaupun ada jumlahnya di setiap lembaga tidak sampai 5 orang.

Lebih sedikitnya jumlah laki-laki dan begitu dominannya perempuan dalam profesi guru PAUD banyak dikaitkan dengan stereotip terhadap profesi guru PAUD itu sendiri. Guru PAUD cenderung digambarkan dengan citra feminin yang dimiliki perempuan. Contohnya, seorang guru PAUD memiliki citra sosok yang keibuan, lemah lembut, penyayang, pandai menari dan menyanyi, pandai mendongeng, dan sebagainya. Karakter-karakter tersebut dalam persepsi masyarakat umumnya sangat lekat dengan sifat feminin dan lebih keperempuanan. Contohnya saja untuk sosok yang pandai menari dan menyanyi maka seseorang tersebut dianggap sudah pasti memiliki sifat gemulai dan luwes dalam gerak-geriknya. Konstruk berpikir seperti ini sudah umum bagi kebanyakan orang. Padahal tidak selalu orang yang gerak-geriknya gemulai dan pandai menari ataupun menyanyi harus dianggap feminin. Boleh jadi ada laki-laki yang dalam menjalankan profesi yang menuntut kemampuan demikian ia mampu melakukannya dengan profesional, sesuai dengan karakter yang diharuskan, namun di luar atau dalam kehidupan sehari-harinya ia juga mampu untuk bersikap maskulin.

Dever dan Falconer (2007) yang mengutip dari Beatty (1995) juga mengungkapkan bahwa secara tradisional, pengajaran anak-anak (yang masih kecil) dianggap sebagai pekerjaan bagi perempuan. Hal ini dikarenakan para guru dari anak-anak usia dini diharapkan untuk menunjukkan kasih 'keibuan' dan kualitas pengasuhan yang baik. Karena itu, selalu diyakini bahwa wanita paling

32 Mukhlis, "Dominasi Guru Perempuan Dalam Pendidikan Anak Usia Dini: Persepsi Stakeholder."

${ }^{33}$ Hasil Wawancara dengan pihak pengelola Program Studi PIAUD IAIN Jember, 2 Mei 2020.

${ }^{34}$ Ikhtisar Data Pendidikan \& Kebudayaan 2017/2018, Pusat Data Dan Statistik Pendidikan Dan Kebudayaan Sekretariat Jenderal Kementerian Pendidikan Dan Kebudayaan (Jakarta, 2017). 
cocok untuk tugas itu. Sedangkan bagi laki-laki yang memasuki dunia pendidikan anak-anak harus siap mengatasi pandangan masyarakat tersebut. Karena mengajar anak-anak kecil sudah lama dianggap sebagai pekerjaan wanita, masyarakat pun sering merasa sulit untuk menerima kondisi bahwa ada pula pria yang ingin bekerja dengan anak-anak. ${ }^{35}$

Stereotip dan pemberian identitas maskulin maupun feminin juga sampai kepada aspek keahlian yang dimiliki oleh guru di lembaga pendidikan anak usia dini. Beberapa mata pelajaran tertentu cenderung mempunyai citra maskulin bagi sebagian orang sehingga dianggap lebih pas untuk diajarkan oleh seorang lakilaki. Seperti contoh kasus pemberian identitas terhadap guru olahraga yang informasinya didapat dari dialog yang dengan para guru laki-laki di Australia berikut. Harris dan Barnes (2009) dalam Watson (2014) menyatakan bahwa Ned, seorang guru taman kanak-kanak di Australia, memandang dirinya dalam posisi yang lebih baik untuk mengajar olahraga tradisional Australia seperti sepakbola dan Kriket. Seorang pengajar olahraga dalam persepsi guru di sana mengekspresikan maskulinitas tradisional. Oleh karenanya positioning ahli dalam bidang olahraga cenderung melekat kepada seorang guru laki-laki. ${ }^{36}$

Pemberian label yang bahkan sampai pada jenis tugas-tugas dan bidang keahlian guru dalam dunia pendidikan tidak dapat dipungkiri masih banyak terjadi. Sering kita membaca dan mendengar adanya kasus pemilahan tugas dalam mengajarkan jenis mata pelajaran tertentu berdasarkan alasan gender. Bahkan sebagian besar dari masyarakat kita mungkin tidak menyadari bahwa kebanyakan guru olahraga di sekolah adalah laki-laki. Ini tidak hanya terjadi di jenjang anak usia dini tapi juga di jenjang SD, SMP dan SMA, di mana guru lakilaki akan cenderung berada dalam bidang pembelajaran olahraga. Bahkan di SD, SMP dan SMA jarang dapat ditemukan seorang guru olahraga perempuan terutama di lingkungan, mungkin ada hanya sebagian kecil. Masyarakat pun tidak banyak bertanya tentang hal ini dan tidak ingin mempermasalahkannya karena sudah dianggap hal yang lazim. Padahal bisa jadi selama ini kita, dengan langsung ataupun tidak, membiarkan bergemanya stigma seputar jenis tugas dan keahlian guru berkembang sebagai suatu stereotip. Sehingga tugas dan bidang keahlian tertentu dipandang mempunyai kesan lebih maskulin dan superior dibandingkan tugas atau bidang keahlian lainnya.

Di sisi lain, profesi guru PAUD belum tergolong sebagai profesi yang menjanjikan secara finansial. Bahkan di sebagian besar daerah, guru yang mengajar di lembaga PAUD maupun taman kanak-kanak belum mendapatkan gaji memenuhi standar upah minimal. Hal ini juga dikemukakan oleh Thornton \& Bricheno dalam Dever dan Falconer (2007), bahwa status rendah dan gaji rendah yang khas dari pekerjaan yang identik sebagai pekerjaan perempuan ini membuat laki-laki enggan mengajar anak-anak kecil. ${ }^{37}$ Di samping itu perempuan bagi sebagian besar budaya masyarakat di Indonesia tidak diposisikan sebagai tulang punggung dalam rumah tangga. Sehingga besaran upah yang diterima tidak

35 Martha T. Dever and Renee C. Falconer, Foundations and Change in Early Childhood Education (Hoboken-New Jersey: John Wiley \& Sons, Inc, 2008).

${ }^{36}$ Lemuel W. Watson, It Takes Team Effort: Men and Women Working Together to Enhance Children's Lives (Charlotte-North Carolina: Informatien Age Publishing, Inc, 2014).

37 Dever and Falconer, Foundations and Change in Early Childhood Education. 
terlalu menjadi masalah besar bagi mereka. Hal ini yang sering menyebabkan pekerjaan yang identik dengan perempuan identik pula dengan upah yang rendah.

Pekerjaan sebagai guru PAUD dan taman kanak-kanak bagi sebagian besar orang juga dianggap sebagai profesi dengan minim risiko (low-risk) dan tergolong dalam sektor tradisional. Sedangkan yang dipandang lebih sesuai untuk sektor ini adalah perempuan. Karena berisiko rendah, profesi guru juga dipandang tidak memerlukan keahlian khusus ataupun kemampuan tingkat tinggi sehingga cenderung dianggap pekerjaan yang tidak menantang (unattractive career). ${ }^{38}$ Sedangkan pekerjaan dan profesi yang tergolong berisiko tinggi dipandang lebih sesuai kepada laki-laki.

Selain adanya stigma maskulinitas-feminitas dan gaji yang rendah, guru anak usia dini juga dikaitkan dengan status yang rendah (low status) sebagaimana yang dikemukakan oleh Getswicki dan Bertrand berikut :

"We have already discussed the relatively low status accorded to early childhood teachers, and many men are reluctant to enter a field that is accorded so little recognition. Many men also report that family, friends and even academic counsellors strongly discourage their working with young children, as the feel it is far beneath their talents." 39

Berbagai persepsi negatif yang mengitari profesi guru anak usia dini dapat disinyalir mempengaruhi alasan laki-laki, bahkan mungkin juga perempuan dalam memilih pekerjaan, untuk tidak menjadikan profesi guru anak uisa dini sebagai pilihan utama. Bahkan bisa jadi pula hal ini terjadi sebelumnya pada saat seseorang memilih bidang studi di jenjang kuliah. Sehingga tidak mengejutkan bila program studi pendidikan anak usia dini tidak hanya sepi dari peminat laki-laki, tetapi bisa jadi salah satu program studi dengan peminat paling sedikit jumlahnya dibandingkan dengan program studi lainnya. Faktor-faktor inilah yang bisa jadi berkontribusi pada kurangnya guru laki-laki di ruang kelas anak usia dini. Persepsi masyarakat bertahan dari masa ke masa dalam rentang waktu yang cukup lama sehingga sulit dihapuskan. Anak-anak di masa lampau telah mempunyai persepsi gender yang tertanam tentang gurunya yang diperkuat juga oleh persepsi guru dan orang tuanya. Demikian di masa berikutnya persepsi yang keliru diwariskan turun-temurun.

Persepsi bernada stereotip dalam profesi guru PAUD tidak dapat dilepaskan dari stereotip gender, di mana laki-laki dan perempuan cenderung dibedakan sifat dan karakteristiknya berdasarkan penilaian subyektif. Menurut Hetty Siregar (2001), perempuan dinilai lebih peka. Sehingga pada praktiknya mereka banyak dilibatkan dalam komunikasi inter-personal. Kegiatan-kegiatan sosial umumnya banyak melibatkan komunikasi inter-personal ini dan karena sebab itulah bidang pekerjaan yang melibatkan aktivitas komunikasi inter-personal umumnya didominasi oleh kaum perempuan. Salah satu contohnya adalah pekerjaan sebagai guru taman kanak-kanak. ${ }^{40}$ Pendapat ini juga dikuatkan oleh Williams (1995), bahwa wanita yang bekerja dalam suatu profesi umumnya cenderung diharapkan

\footnotetext{
${ }^{38}$ Elizabeth Burn and Simon Pratt-Adams, Men Teaching Children 3-11: Dismantling Gender Barriers, 1st ed. (London: Bloomsbury Academic, 2015).

39 Carol Gestwicki and Jane Bertrand, Essentials of Early Childhood Education - Carol Gestwicki, Jane Bertrand - Google Books, 4th ed. (Toronto: Nelson Education, Ltd., 2011). 40 Hetty Siregar, Menuju Dunia Baru (Jakarta: BPK Gunung Mulia, 2001).
} 
memiliki atribut feminin seperti memberi perhatian, orientasi pada pelayanan, dan serta daya tarik seksual dan semua kualitas yang terkait dengan fungsi domestik tradisional wanita. Atribut-atribut seperti ini sering ditekankan dalam penggambaran media populer tentang wanita terutama dalam pekerjaan-pekerjaan seperti: perawat, pustakawan, pekerja sosial dan guru di sekolah. ${ }^{41}$

Bahkan di Amerika, terdapat stereotip yang menggambarkan laki-laki memiliki sifat aktif-instrumental, seperti daya saing dan dominasi, dan perempuan memiliki sifat ekspresif-pengasuhan, seperti sensitivitas dan kasih sayang. Pria juga dianggap lebih unggul dalam matematika, sains, dan kegiatan mekanis; perempuan pada kegiatan verbal dan pengasuhan (nursing). Laki-laki diharapkan menjadi penghasil pendapatan utama dalam keluarga. Selain itu, kualitas yang terkait dengan pria memiliki status lebih tinggi dan lebih kuat daripada kualitas yang terkait dengan wanita. ${ }^{42}$ Padahal negara ini merupakan rujukannya demokrasi, keadilan dan kesetaraan gender.

Sebagian masyarakat menerima konsep perempuan sebagai makhluk yang lebih emosional, sedangkan laki-laki lebih rasional. Sehingga dalam beberapa jenis pekerjaan ataupun profesi tertentu perempuan dianggap lebih cocok dibandingkan laki-laki, termasuk menjadi guru bagi anak-anak usia dini. Padahal profesi tidak berkaitan dengan masalah identitas gender seseorang. Artinya, siapapun boleh memilih profesi tertentu yang sesuai dengan passion-nya, lebih-lebih bila menggunakan alasan bahwa jenis seks tertentu lebih emosional dibandingkan jenis seks lainnya. Sungguh suatu kesimpulan yang terburu-buru. Padahal lakilaki dan perempuan sama-sama merupakan makhluk tuhan yang dibekali emosi dan rasio dengan variasi yang tidak bisa disamaratakan di setiap individunya.

Karakterisasi terhadap laki-laki dan perempuan sebagai dua subyek yang berbeda turut menjadi pangkal dari lahirnya persepsi, yang pada akhirnya mengakibatkan pemilahan peran dan tugas. Menurut Siregar, anggapan bahwa perempuan lebih dianggap sebagai makhluk emosional dibanding makhluk rasional merupakan anggapan yang menyesatkan. Pembagian kerja secara seksual merupakan pembagian kerja yang berdasarkan seksisme dan termasuk bentuk stereotipe gender. Padahal secara ilmiah para ahli telah membuktikan bahwa kemampuan otak perempuan sama dengan kemampuan otak laki-laki. Sehingga apabila perempuan cenderung lebih emosional maka ini tidak ada sangkutpautnya dengan kemampuan otak, melainkan sebagai ciri atau kekhasan kaum perempuan. ${ }^{43}$

\section{Peran Laki-Laki Dalam Profesi Guru Pendidikan Anak Usia Dini}

Memahami peran ayah dalam pendidikan anak usia dini harus diawali dari pemahaman tentang peran orang tua (laki-laki dan perempuan) dalam keluarga. Karena pendidikan bagi anak usia dini sesungguhnya dimulai dari keluarga. Peran sebagai orang tua (parenthood) secara alamiah adalah peran yang lahir bersamaan dengan kehadiran seorang anak dalam keluarga. Sejak itulah fungsi dan tanggung jawab sebagai ayah dan ibu terhadap anaknya dimulai. Keduanya saling

${ }^{41}$ Christine L. Williams, Still a Man's World: Men Who Do Women's Work (London: University of California Press, 1995).

${ }^{42}$ Roger J.R. Levesque, Encyclopedia of Adolescence, Encyclopedia of Adolescence (New York: Springer, 2011), https://doi.org/10.1007/978-1-4419-1695-2.

43 Siregar, Menuju Dunia Baru. 
melengkapi dan mengisi. Oleh karenanya peran orang tua termasuk dalam hal mendidik dan membimbing merupakan peran yang dijalankan ayah maupun ibu, bukan ayah saja atau ibu saja.

Mengaitkan peran guru anak usia dini di sekolah hanya dengan tugas perempuan yang erat dengan tanggung jawab keibuannya (motherhood) dalam rumah tangga adalah tidak tepat. Lebih-lebih bila didasarkan pada dalil yang disalahpahami penafsirannya. Sebab sesungguhnya dalam Islam ayah mempunyai tanggung jawab untuk melindungi dirinya dan keluarganya dari api neraka. Sebagaimana yang Allah sampaikan dalam al-Qur'an Surah at-Tahrim ayat 6 :

"Hai orang-orang yang beriman, peliharalah dirimu dan keluargamu dari api neraka yang bahan bakarnya adalah manusia dan batu; penjaganya malaikat-malaikat yang kasar, keras, dan tidak mendurhakai Allah terhadap apa yang diperintahkan-Nya kepada mereka dan selalu mengerjakan apa yang diperintahkan." ${ }^{44}$

Menurut Shihab, ayat tersebut secara redaksional tertuju pada laki-laki. Kata 'quu anfusakum' mengandung amar (perintah) dengan kata ganti pria jamak. Namun ini tidak berarti perintahnya tertuju hanya bagi ayah saja. Ayat ini berhubungan dengan pria dan wanita (suami-istri), sebagaimana pada ayat ayat tetang puasa yang juga dimaksudkan bagi laki-laki dan perempuan. Artinya ayah dan ibu bertanggung jawab terhadap anak-anak juga pasanganya masing-masing. Pendidikan harus dimulai dari rumah. Peran ayah saja atau ibu saja tidak cukup untuk menciptakan satu rumah tangga yang diliputi oleh nilai-nilai agama serta dibayangi oleh hubungan yang harmonis. 45 Tanggung jawabnya di sini dapat dikonversikan ke berbagai bentuk tindakan, termasuk di dalamya adalah kegiatan mendidik anak-anaknya.

Di samping itu islam hadir di tengah-tengah manusia dengan tujuan membebaskan dari berbagai bentuk ketidakadilan. Hubungan antar manusia dalam islam didasarkan atas prisip-prinsip kesetaraan, persaudaraan dan kemaslahatan. Meskipun di dalam al-Qur'an diakui adanya perbedaan antara lakilaki dan perempuan, namun perbedaan yang dimaksud bukan tidak sama dengan pembedaan yang dapat menguntungkan salah satu pihak dan merugikan pihak lainnya. Perbedaan antara keduanya dimaksudkan untuk mendukung misi pokok agama, yaitu terciptanya hubungan yang harmonis yang didasari oleh kasih sayang dalam keluarga. 46

Untuk itu, di dalam keluarga penting ditanamkan konsep pola asuh kemitraan (partnership parenting) untuk menciptakan harmonisasi peran ayah dan ibu. Menurut Pruetts (2009) ketika dua orang dewasa berbagi pengasuhan (partnership parenting) dengan seorang anak, sifat dan kualitas hubungan antara orang-orang dewasa itu akan berdampak kuat pada perkembangan anak. ${ }^{47}$ Partnership parenting dapat terjadi ketika suami dan istri menyadari bahwa keduanya mempunyai tujuan sama dan saling mendukung untuk tujuannya

44 "At-Tahrim - النحريم | Qur'an Kemenag," accessed June 10, 2020, https://quran.kemenag.go.id/sura/66.

${ }^{45}$ Moh. Quraish Shihab, Tafsir Al-Mishbah: Pesan, Kesan Dan Keserasian Al-Qur'an (Ciputat: Lentera Hati, 2000).

${ }^{46}$ Khaeron Sirin, Perkawinan Mazhab Indonesia: Pergulatan Antara Negara, Agama, Dan Perempuan, 1st ed. (Yogyakarta: Depublish, 2018).

${ }^{47}$ Kyle Pruett and Marsha Pruett, Partnership Parenting: How Men and Women Parent Differently -- Why It Helps ... (Massachussets: Da Capo Lifelong Books, 2009). 
dengan keunikan masing-masing. Untuk itu mereka saling berbagi tanggung jawab, membuat keputusan bersama-sama, kompak dan saling berkomitmen. Sehingga tidak terjadi dominasi pada salah satu pihak dan tidak ada yang lebih menang dan kalah di pihak lain. Laki-laki sebagai ayah dan perempuan sebagai ibu berperan secara seimbang.

Oleh karenanya, berkaca pada peran ayah dan ibu dalam keluarga, maka seharusnya ada keterwakilan peran dari sosok ayah di sekolah selain adanya peran sosok ibu. Dalam pendidikan anak usia dini peran guru laki-laki sangat penting di samping peran guru perempuan. Keseimbangan peran tersebut erat kaitannya dengan kemampuan anak dalam memproyeksikan fungsi dan peran ayah dan ibu dalam kehidupannya sehari-hari, serta agar tidak terjadi persepsi stereotip terhadap keberadaan guru laki-laki sebagai pendidik di kelas. Bahwa anak laki-laki pun bisa menjadi guru PAUD dan taman kanak-kanak. Atau boleh jadi terdapat anak yang terpaksa tidak mendapatkan kasih sayang seorang ayah di rumah karena orang tuanya bercerai, namun di kelas ia menemukan sosok yang dapat mengobati kekurangannya tersebut.

Di samping itu, pendidikan anak usia dini merupakan garda terdepan dalam meng-counter rendahnya literasi masyarakat terhadap gender melalui pengenalan tentang gender bagi anak sejak dini. Mengutip pendapat Santrock "Gender is another key dimension of children's development". Pentingnya mengenalkan peran gender sejak dini sangat erat kaitannya dengan perkembangan dan pembentukan pola perilaku dan kepribadian anak di masa dewasa. Oleh karena itu segala jenis informasi yang benar dan berkaitan erat dengan peran gender harus ditanamkan secara tepat agar dapat tersimpan di memori anak dalam jangka panjang. ${ }^{48}$

Di sisi lain, keberadaan guru laki-laki dalam pendidikan anak usia dini tak sekedar soal mewujudkan keseimbangan peran gender, tetapi juga mengikis pemikiran stereotip yang terlanjur subur di masyarakat. Masyarakat juga perlu mempertimbangkan pandangan lainnya yang tidak selalu memberikan label negatif bagi laki-laki yang bekerja sebagai guru TK. Sebuah penelitian yang dilakukan oleh Aliansi Pembelajaran Pra-sekolah pada tahun 2011 menemukan bahwa sebenarnya $98 \%$ orang tua mendukung pria yang bekerja dalam pengasuhan anak dengan usia tiga hingga lima tahun dan lebih dari $90 \%$ orang tua menyetujui pria yang bekerja dengan bayi, balita, dan anak usia dua tahun. ${ }^{49}$ Artinya, tidak semua orang menganggap laki-laki yang menjadi guru PAUD dan TK sebagai sesuatu yang tidak pantas.

Pendidikan merupakan kunci bagi terwujudnya keadilan gender. Karena pendidikan merupakan tempat masyarakat mentransfer norma-norma, pengetahuan, dan kemampuan mereka. ${ }^{50}$ Oleh karenanya perhatian pemerintah sangat penting untuk mengatasi problem kesejahteraan guru di lingkungan PAUD, terutama untuk menghapus stigma yang melekat pada profesi guru PAUD sebagai

\footnotetext{
48 John W. Santrock, Life - Span Development: Perkembangan Masa Hidup Jilid 1, ed. Herman Sinaga and Yati Sumiharti, Ed. ke-5 (Jakarta: Erlangga, 1995).

49 Jo Josephidou and Polly Bolshaw, Understanding Gender and Early Childhood: An Introduction to the Key Debates, 1st ed. (New York: Routledge, 2020).

50 Novita Indarni, "Efektivitas Cerita Bergambar Terhadap Pemahaman Peran Gender Pada Anak Di Taman Kanak-Kanak," Indonesian Journal of Early Childhood Education Studies 1, no. 1 (May 14, 2012), https://doi.org/10.15294/ijeces.v1i1.9196.
} 
pekerjaan dengan gaji rendah. Peningkatan kesejahteraan guru PAUD harus mendapatkan perhatian khusus. Untuk itu, harus ada upaya tersistematis mulai dari atas hingga ke akar rumput untuk bisa mewujudkan keseimbangan peran laki-laki dan perempuan di PAUD. Sistem yang tak hanya menciptakan kesetaraan akses dan peluang laki-laki dan perempuan untuk terjun ke bidang pendidikkan anak usia dini, tetapi juga memberikan kepastian promosi yang menarik dan menjanjikan bagi kesejahteraan guru, baik laki-laki maupun perempuan.

\section{Kesimpulan}

Berdasaran dikusi sebelumnya, dapat disimpulkan bahwa :

1. Stereotip gender dalam profesi guru pendidikan anak usia dini setidaknya berwujud dalam tiga hal : a) pemberian identitas feminin dan jauh dari kesan maskulin, sehingga laki-laki kurang tertarik mengajar anak usia dini; b) guru PAUD dan taman kanak-kanak dianggap sebagai profesi dengan minim risiko (low-risk) dan tergolong dalam sektor tradisional sehingga kurang menantang dan yang dipandang lebih sesuai untuk sektor ini adalah perempuan; c) guru PAUD adalah pekerjaan bergaji rendah dan dianggap lebih sesuai dilakukan oleh perempuan. Oleh karenanya literasi dan kepekaan informasi masyaraat terhadap isu gender harus ditingkatkan. Pemahaman yang benar terhadap gender justru dibutuhkan untuk dapat mengikis bentuk-bentuk ketidakadilan gender di masyarakat, termasuk stereotip.

2. Problem stereotip gender dalam profesi guru pendidikan anak usia dini di Indonesia seharusnya menjadi perhatian bagi seluruh pengelola pendidikan anak usia dini, mulai dari tingkat pusat sampai ke lembaga PAUD. Karena pendidikan anak usia dini adalah gerbang utama generasi kita dalam mengenyam pendidikan serta awal yang penting dalam membantu tumbuh kembang serta potensi peserta didik yang optimal.

3. Harus ada upaya tersistematis untuk bisa mewujudkan keseimbangan peran laki-laki dan perempuan di PAUD. Sistem yang tak hanya menciptakan kesetaraan akses dan peluang laki-laki dan perempuan untuk terjun ke bidang pendidikkan anak usia dini, tetapi juga memberikan kepastian promosi yang menarik dan menjanjikan bagi kesejahteraan guru laki-laki maupun perempuan. Perhatian pemerintah sangat penting untuk mengatasi problem kesejahteraan guru di lingkungan PAUD dan taman kanak-kanak untuk menghapus stigma yang melekat pada profesi guru PAUD sebagai pekerjaan dengan gaji rendah.

\section{Referensi}

Arbain, Janu, Nur Azizah, and Ika Novita Sari. "PEMIKIRAN GENDER MENURUT PARA AHLI: Telaah Atas Pemikiran Amina Wadud Muhsin, Asghar Ali Engineer, Dan Mansour Fakih." Sawwa: Jurnal Studi Gender 11, no. 1 (June 7, 2017): 75. https://doi.org/10.21580/sa.v11i1.1447.

"Arti Kata Stereotip - Kamus Besar Bahasa Indonesia (KBBI) Online." Accessed May 9, 2020. https://kbbi.web.id/stereotip.

“At-Tahrim - التحريم | Qur'an Kemenag." Accessed June 10, 2020. 
https:/ /quran.kemenag.go.id/sura/66.

Brzuzy, Stephanie, and Amy Lind. Battleground: Women, Gender, and Sexuality [2 Volumes]. Greenwood Press. Westport, Connecticut, 2008.

Burn, Elizabeth, and Simon Pratt-Adams. Men Teaching Children 3-11: Dismantling Gender Barriers. 1st ed. London: Bloomsbury Academic, 2015.

Clara, Evy, and Ajeng Agrita Dwikasih Wardani. Sosiologi Keluarga. Jakarta: UNJ Press, 2020.

D., Wiliam-de Vries. Gender Bukan Tabu: Catatan Perjalanan Fasilitasi Kelompok Perempuan Di Jambi. Gender Bukan Tabu: Catatan Perjalanan Fasilitasi Kelompok Perempuan Di Jambi. Bogor: Center for International Forestry Research (CIFOR), 2006. https://doi.org/10.17528/cifor/002133.

Dever, Martha T., and Renee C. Falconer. Foundations and Change in Early Childhood Education. Hoboken-New Jersey: John Wiley \& Sons, Inc, 2008.

WHO Europe. "Gender: Definitions," 2002. https://www.euro.who.int/en/healthtopics/health-determinants/gender/gender-definitions.

"Gender." Accessed June 9, 2020. https://www.who.int/healthtopics /gender\#tab=tab_1.

Gestwicki, Carol, and Jane Bertrand. Essentials of Early Childhood Education Carol Gestwicki, Jane Bertrand - Google Books. 4th ed. Toronto: Nelson Education, Ltd., 2011.

Kementerian Pemberdayaan Perempuan dan Anak Republik Indonesia. "Glosary Ketidakadilan Gender," n.d.

Gomes, Fransiskus de. "DAMPAK DOMINASI PEREMPUAN DALAM PROFESI GURU PAUD.” Jurnal Inovasi Pendidikan Dasar 2, no. 1 (2008): 86-97.

Ho, Dora, and Haze Lam. "A Study of Male Participation in Early Childhood Education: Perspectives of School Stakeholders." International Journal of Educational Management 28, no. 5 (2014): 498-509. https://doi.org/10.1108/IJEM-02-2013-0024.

Ikhtisar Data Pendidikan \& Kebudayaan 2017/2018. Pusat Data Dan Statistik Pendidikan Dan Kebudayaan Sekretariat Jenderal Kementerian Pendidikan Dan Kebudayaan. Jakarta, 2017.

Indarni, Novita. "Efektivitas Cerita Bergambar Terhadap Pemahaman Peran Gender Pada Anak Di Taman Kanak-Kanak." Indonesian Journal of Early Childhood Education Studies 1, no. 1 (May 14, 2012). https://doi.org/10.15294/ijeces.v1i1.9196.

Irianto, Sulistyowati, Henky Irzan, Lim Sing Meij, Theresia Dyah Wirastri, Tirtawening Parikesit, Titik Kartika, and Vidhyandika D. Perkasa. Akses Keadilan Dan Migrasi Global: Kisah Perempuan Indonesia Pekerja ... Jakarta: Yayasan Pustaka Obor Indonesia, 2011.

Jordan, Rosena. "Why We Need More Male Teachers and More Female Principals Independent.Ie." Independent.ie, 2016. https://www.independent.ie/irishnews / education/going-to-college/why-we-need-more-male-teachers-and-morefemale-principals-35083784.html.

Josephidou, Jo, and Polly Bolshaw. Understanding Gender and Early Childhood: An 
Introduction to the Key Debates. 1st ed. New York: Routledge, 2020.

Levesque, Roger J.R. Encyclopedia of Adolescence. Encyclopedia of Adolescence. New York: Springer, 2011. https://doi.org/10.1007/978-1-4419-1695-2.

Lippmann, Walter. "Stereotypes." In Public Opinion., 79-94. MacMillan Co, 2015. https://doi.org/10.1037/14847-006.

Merwe, Chris N. van der. Breaking Barriers. Stereotypes and the Changing of Values in Afrikaans Writing 1875-1990. Amsterdam: Rodopi, 1994.

Mukhlis, Akhmad. "Dominasi Guru Perempuan Dalam Pendidikan Anak Usia Dini: Persepsi Stakeholder." Al-Athfal Jurnal Pendidikan Anak 5, no. 2 (2019): 11734.

http:/ / ejournal.uinsuka.ac.id/tarbiyah/index.php/alathfal/article/view/2619/1753.

Pendidikan, Kementerian, D A N Kebudayaan, Pusat Data, D A N Statistik, and Pendidikan Dan. 2017 18. Edited by Pusat Data Statistik Pendidikan dan Kebudayaan. Jakarta: Kemendikbud RI, 2018.

Pruett, Kyle, and Marsha Pruett. Partnership Parenting: How Men and Women Parent Differently -- Why It Helps ... Massachussets: Da Capo Lifelong Books, 2009.

Santrock, John W. Life - Span Development: Perkembangan Masa Hidup Jilid 1. Edited by Herman Sinaga and Yati Sumiharti. Ed. ke-5. Jakarta: Erlangga, 1995.

Saptari, Ratna, Brigitte M. Holzner, and Kalyanamitra. Perempuan, Kerja, Dan Perubahan Sosial: Sebuah Pengantar Studi Perempuan. Pustaka Utama Grafiti, 1997.

https://books.google.co.id/books/about/Perempuan_kerja_dan_perubahan_so sial.html?hl=id\&id=jHDaAAAAMAAJ\&redir_esc=y.

Secord, Paul F., and Carl W. Backman. Social Psychology - Paul F. Secord, Carl W. Backman. New York: McGraw Hill Book Company, 1964.

Shihab, Moh. Quraish. Tafsir Al-Mishbah: Pesan, Kesan Dan Keserasian Al-Qur'an. Ciputat: Lentera Hati, 2000.

Siregar, Hetty. Menuju Dunia Baru. Jakarta: BPK Gunung Mulia, 2001.

Sirin, Khaeron. Perkawinan Mazhab Indonesia: Pergulatan Antara Negara, Agama, Dan Perempuan. 1st ed. Yogyakarta: Depublish, 2018.

Soeroso, Moerti Hadiati. Kekerasan Dalam Rumah Tangga Dalam Perspektif YuridisViktimologis. Sinar Grafika, 2010.

Sum, Theresia Alviani. "Opini: PAUD Dan Peran Guru Laki-Laki | Florespost.Co." Florespost.Co, June 4, 2018. https://www.florespost.co/2018/06/04/opinipaud-dan-peran-guru-laki-laki/.

Sum, Theresia Alviani, Adriani Tamo, and Ina Talu. "Faktor Penyebab Kurangnya Minat Laki-Laki Untuk Menjadi Guru Paud Di Kabupaten Manggarai." Missio, no. $10 \quad$ (2003): 192-203. http://jurnal.unikastpaulus.ac.id/index.php/jpkm/article/view/170/139.

Wahyuni, Nopitri. "Indonesia Dalam Gender Gap Index 2020 Report: Beberapa Catatan." The Indonesian 2019. https://www.theindonesianinstitute.com/indonesia-dalam-gender-gap-index- 
2020-report-beberapa-catatan/.

Watson, Lemuel W. It Takes Team Effort: Men and Women Working Together to Enhance Children's Lives. Charlotte-North Carolina: Informatien Age Publishing, Inc, 2014.

Williams, Christine L. Still a Man's World: Men Who Do Women's Work. London: University of California Press, 1995.

World Economic Forum. "Insight Report Global Gender Gap Report 2020 Terms of Use and Disclaimer." Switzerland, 2019. www.weforum.org.

Zed, Mestika. Metode Penelitian Kepustakaan. 2nd ed. Jakarta: Yayasan Pustaka Obor Indonesia, 2008. 